Literature, Rhetoric and Violence in Northern Ireland, 1968-98 
Also by Patrick Grant

A DAZZLING DARKNESS: An Anthology of Western Mysticism

BREAKING ENMITIES: Religion, Literature and Culture in Northern Ireland, 1967-97

IMAGES AND IDEAS IN LITERATURE OF THE ENGLISH RENAISSANCE

LITERATURE AND PERSONAL VALUES

LITERATURE OF MYSTICISM IN WESTERN TRADITION

PERSONALISM AND THE POLITICS OF CULTURE

READING THE NEW TESTAMENT: Literature and the Discovery of Method in the English Renaissance

SIX MODERN AUTHORS AND PROBLEMS OF BELIEF

SPIRITUAL DISCOURSE AND THE MEANING OF PERSONS

THE TRANSFORMATION OF SIN: Studies in Donne, Herbert, Vaughan and Traherne 


\section{Literature, Rhetoric and Violence in \\ Northern Ireland, 1968-98}

\section{Hardened to Death}

Patrick Grant

Professor of English

University of Victoria

British Columbia

Canada 


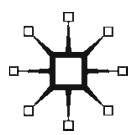

(C) Patrick Grant 2001

Softcover reprint of the hardcover 1st edition 2001 978-0-333-79412-8

All rights reserved. No reproduction, copy or transmission of this publication may be made without written permission.

No paragraph of this publication may be reproduced, copied or transmitted save with written permission or in accordance with the provisions of the Copyright, Designs and Patents Act 1988, or under the terms of any licence permitting limited copying issued by the Copyright Licensing Agency, 90 Tottenham Court Road, London W1T 4LP.

Any person who does any unauthorised act in relation to this publication may be liable to criminal prosecution and civil claims for damages.

The author has asserted his right to be identified as the author of this work in accordance with the Copyright, Designs and Patents Act 1988.

First published 2001 by

PALGRAVE

Houndmills, Basingstoke, Hampshire RG21 6XS and 175 Fifth Avenue, New York, N. Y. 10010

Companies and representatives throughout the world

PALGRAVE is the new global academic imprint of

St. Martin's Press LLC Scholarly and Reference Division and Palgrave Publishers Ltd (formerly Macmillan Press Ltd).

ISBN 978-1-349-42006-3 ISBN 978-0-230-59695-5 (eBook)

DOI $10.1057 / 9780230596955$

This book is printed on paper suitable for recycling and made from fully managed and sustained forest sources.

A catalogue record for this book is available from the British Library.

Library of Congress Cataloging-in-Publication Data

Grant, Patrick.

Literature, rhetoric, and violence in Northern Ireland, 1968-98 : hardened to death / Patrick Grant.

p. $\mathrm{cm}$.

Includes bibliographical references and index.

1. English literature-Irish authors-History and criticism. 2. Politics and literature-Northern Ireland-History-20th century. 3. Literature and society-Northern Ireland-History-20th century. 4. English language-Northern Ireland-Rhetoric. 5. Northern Ireland-Intellectual life. 6. Northern Ireland-In literature. 7. Political violence in literature. 8. Social conflict in literature. 9. Violence in literature. I. Title.

PR8891.N67 G735 2001

$820.9^{\prime} 358-\mathrm{dc} 21$

$\begin{array}{llllllllll}10 & 9 & 8 & 7 & 6 & 5 & 4 & 3 & 2 & 1\end{array}$

$\begin{array}{llllllllll}10 & 09 & 08 & 07 & 06 & 05 & 04 & 03 & 02 & 01\end{array}$ 
Such is the nature of force. Its power of converting a man into a thing is a double one, and its application double-edged. To the same degree, though in different fashions, those who use it and those who endure it are turned to stone.

Simone Weil, "The Iliad, or The Poem of Force" 
For Gloria 


\section{Contents}

Preface $\quad$ ix

List of Abbreviations $\quad$ xi

1 Introduction: at War with Words 1

$\begin{array}{ll}\text { On violence, broadly speaking } & 1\end{array}$

Refining the criteria: Vergil and the Gospels 6

$\begin{array}{ll}\text { Northern Ireland and the historical debate } & 11\end{array}$

2 The Iron Circle: on the Core Mechanisms of Violence 16

Entrapment: variations on a theme 16

Michael Longley: violence and the fragility of the civilized 29

Brian Friel's Bloody Sunday: art containing outrage 38

3 Equivocations of the Fiend: Self-Deception and

$\begin{array}{ll}\text { Poetic Diction } & 47\end{array}$

Confused and complex diction: Seamus Heaney and others $\quad 47$

Lies, delusions and propaganda $\quad 54$

Getting a perspective: Derek Mahon's "semantic scruples" 61

4 The God of Battles: Violence and Sectarianism 66

How important is religion, really? $\quad 66$

The return of the repressed: Padraic Fiacc and Billy Wright $\quad 77$

"Werewolves in Magherafelt": David Rudkin and Field Day 83

5 Shoot the Women First 93

Subversion, incoherence and non-violence:

Medbh McGuckian and others 93

Representing violent women:

$\begin{array}{ll}\text { stereotypes and hybrid fantasies } & 100\end{array}$

Dealing with it: women and violence in

Maurice Leitch, Jennifer Johnston and Nuala O'Faolain 108

$\begin{array}{lll}6 & \text { Breaking the Circle } & 121\end{array}$

"Pardon like rain": John Hewitt, Gordon Wilson and others 121

Forgiveness and injury: Frank McGuinness and

Robert McLiam Wilson 130

Moral imagination and the rhetoric of reconciliation:

John Hume, David Trimble and Bernard MacLaverty 
viii Contents

7 Conclusion

Notes

157

Index

168 


\section{Preface}

While researching and writing an earlier book, Breaking Enmities: Religion, Literature and Culture in Northern Ireland, 1967-97, I found myself noticing two quite simple points more or less independently of my main enquiry. The first is how extraordinary is the documentation pertaining to the Troubles in Northern Ireland during the past thirty years. I had known that John Whyte once described Northern Ireland as, per capita, probably the most intensely researched community on earth, and that Robert Fisk singled out the political collection in the Linen Hall Library as unique because of the unmatched insight it provides into all shades of opinion about the conflict. I was familiar with these views and others like them, but only gradually came to realize how much the remarkable archive of printed materials pertaining to the Troubles has to offer to students of violent conflict not only in Northern Ireland but in general. Within the confines of a society comprising just over 1.5 million people, we can follow the grain lines of a dispute in which the interests of nation states, ethnic minorities, post-colonial economies, globalization, identity politics and urban guerrilla warfare combine and metamorphose in a compelling and bewildering variety of ways. One main legacy of these troubled years in Northern Ireland is therefore likely to be the sheer richness and density of the documentation provided by sociological and political commentary, journalism, biography, memoirs, academic research, political pamphleteering of many kinds, and a literary renaissance that has produced an extensive body of writing, often of high quality.

The second point that I came - again gradually - to notice is how perplexed yet captivating are the relationships between words and the actual conduct of violence, and I found myself increasingly preoccupied by the complex ways in which a war of words has accompanied and interpenetrated with the actual war. In this context I also came to realize how the Troubles are deeply and pervasively represented in literature of the period, though not always directly, and usually not in a straightforward partisan fashion. Indeed, one main contribution of a good deal of the literature is to challenge traditional oppositions, disclosing how these contribute to violence and demonstrating why they need to be deconstructed rather than re-confirmed. In short, literature has a lot to say about the seductions, demonic intoxications and inevitable failures 
of violence, communicated through an imagined complexity which is a necessary adjunct to the other forms of written discourse by which the Troubles are recorded.

Understandably, one often feels a disturbing incommensurability between printed records of actual, lethal violence and how violent behaviour is represented in literature. Yet the evaluations and re-evaluations enabled and provoked by works produced by the fictive imagination, as well as by an assessment of how these relate to other forms of discourse, have a vital contribution to make not just in Northern Ireland but in any society concerned to understand how precarious is the order maintained by the rule of law and the conventions of civilized behaviour.

Elsewhere, I have written in detail about some basic positions - religious, political and aesthetic - that also underlie the present study, and in the following pages I attempt to avoid undue theorizing and specialized debate. Although I intend to provide arguments sufficient to sustain the case I want to make, the central idea that literature does not occupy a hermetically sealed, specialized realm will, I hope, sufficiently discourage me from writing as if I inhabit one.

I have received help from a great many people to whom I am immensely indebted, though I will not attempt to list their names here. The Social Sciences and Humanities Research Council of Canada has supported the project through a Standard Research Grant, which I gratefully acknowledge. Permission has been granted by the Blackstaff Press to reproduce "The Iron Circle" from The Collected Poems by John Hewitt; by Jonathan Cape to reproduce "The Civil Servant" and "Wounds" from Selected Poems by Michael Longley; by the Gallery Press to reproduce "Rage for Order" from Collected Poems by Derek Mahon; by the Gallery Press and Wake Forest University Press to reproduce "Apostle of Violence" from Captain Lavender by Medbh McGuckian. 


\section{List of Abbreviations}

$\begin{array}{ll}\text { BBC } & \text { British Broadcasting Corporation } \\
\text { CLMC } & \text { Combined Loyalist Military Command (emerged in 1991 to } \\
& \text { represent loyalist paramilitary interests) } \\
\text { DUP } & \begin{array}{l}\text { Democratic Unionist Party (strongly conservative; founded } \\
\text { in 1971) }\end{array} \\
\text { INLA } & \text { Irish National Liberation Army (an extreme republican } \\
& \text { paramilitary group, founded in 1975; is associated with the } \\
& \text { Irish Republican Socialist Party, IRSP) } \\
& \text { Irish Republican Army (a split in 1970 resulted in two } \\
& \text { organizations, the Officials and the Provisionals, who are } \\
& \text { sometimes designated PIRA. In the present study, IRA } \\
& \text { indicates the provisional wing; is associated with Sinn Féin.) } \\
& \text { Irish Republican Brotherhood (a revolutionary organization } \\
\text { IRB } & \text { founded in 1858; a forerunner of the modern IRA) } \\
\text { IRSP } & \text { Irish Republican Socialist Party (founded in 1974; associated } \\
& \text { with the Irish National Liberation Army, INLA) } \\
\text { LVF } & \text { Loyalist Volunteer Force (extreme loyalist paramilitary } \\
& \text { group, founded in 1996) } \\
\text { MRF } & \text { Mobile Reconnaissance Force } \\
\text { NICRA } & \text { Northern Ireland Civil Rights Association (founded in 1967) } \\
\text { PUP } & \begin{array}{l}\text { Progressive Unionist Party (founded in 1979; associated with } \\
\text { the Ulster Volunteer Force, UVF). }\end{array} \\
\text { RTE } & \text { Radio Telefis Eireann (Irish broadcasting network) } \\
\text { RUC } & \text { Royal Ulster Constabulary (Northern Ireland's police service) } \\
\text { SAS } & \text { Special Air Service (an elite British Army undercover unit) } \\
\text { SDLP } & \text { Social Democratic and Labour Party (mainline nationalist } \\
& \text { party, founded in 1970) } \\
\text { SF } & \text { Sinn Féin (political party associated with the IRA) } \\
\text { UDA } & \text { Ulster Defence Association (loyalist paramilitary group, } \\
& \text { founded in 1971; has used the cover name Ulster Freedom } \\
\text { Fighters, UFF; is associated with the Ulster Democratic Party, } & \text { UDP) } \\
& \text { Ulster Defence Regiment (formed in 1970 to replace the } \\
& \text { B Specials (a part-time police force founded in 1920); merged } \\
& \text { in 1992 with the Royal Irish Rangers to form the Royal Irish } \\
& \text { Regiment) }\end{array}$




\section{xii List of Abbreviations}

UFF Ulster Freedom Fighters (cover name for Ulster Defence Association, UDA)

UUP Ulster Unionist Party (mainline unionist party, which also governed Northern Ireland from 1921 to 1972, when direct rule from London was imposed)

UVF Ulster Volunteer Force (loyalist paramilitary group, formed in 1966; traces its origins to resistance to Home Rule in 1912, and is associated with the Progressive Unionist Party, PUP) 